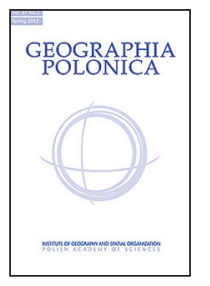

\title{
VISEGRAD COUNTRIES IN GLOBAL PRODUCTION NETWORKS: VALUE CREATION, CONTROL AND CAPTURE
}

\author{
Jana Vlčková \\ World Economy Department, Faculty of International Relations \\ University of Economics \\ W. Churchill Sq. 1938/4, 13067 Prague 3 - Žižkov, Prague: Czech Republic \\ e-mail: jana.vlckova@vse.cz
}

\begin{abstract}
The Visegrad countries have become increasingly integrated into global production networks, mainly due to the increasing share of foreign value added in their exports. The automotive and electronics industries are the most integrated into global production network (GPN) with major role performed by European countries, particularly Germany. There are slight differences between the Visegrad countries, with Poland being much less dependent on exports and foreign capital, particularly due to its larger size. Overall, participation in GPN has brought benefits to the Visegrad nations, although limited attention has been paid to the costs such as dependence on foreign capital and low value control and capture.
\end{abstract}

\section{Key words}

global production networks - Visegrad countries - backward participation $\bullet$ value added $\bullet$ value capture

\section{Introduction}

Over the past three decades there have been huge shifts in the geographical distribution of production processes within many sectors of the economy (Dicken 2015). Several activities have been relocated to emerging economies mainly to East Asia and more recently to Central and Eastern European countries. The production of many commodities is now spread across regions, countries, and continents gathering cost advantages to become globally competitive. Changes in the locations of production have been accompanied by alterations in the organisation of the production process. Over $50 \%$ of globally manufactured imports are intermediate goods and over $70 \%$ of world services imports are intermediate services (De Backer \& Miroudot 2013). Since the 1990s the post-communist Central European countries of Czechia, Hungary, Poland and Slovakia (the so called Visegrad or V4 countries') have become an attrac-

\footnotetext{
${ }^{1}$ The Visegrad Group is an alliance of four countries: Czechia, Slovakia, Hungary and Poland, it was 'established' at a summit in 1991 which was held in the Hungarian castle Visegrad.
} 
tive destination for FDI and many production activities of the old EU member states have been moved to these countries (Pavlínek et al. 2009.). Geographic proximity to Western markets, the availability of skilled and inexpensive labour and economic transformation combined with investment incentives were the major drivers of these FDI inflows (Drahokoupil 2009). The Visegrad countries are with the exception of Poland small and open economies in which the role of exports has increased significantly since the early 1990s, this has been accompanied by further integration of these countries into the global economy.

Participation in the global economy has been associated with specific roles across a number of production networks. Participation in GPN brings benefits but it also raises costs such as stronger competition for local companies, negative environmental and social effects, potential 'footlooseness' of GPN activities and an increased vulnerability to external shocks. To assess the benefits of GPN integration for an economy it is important to answer several questions. How much value is created in the country? Does the country control how and what is being produced? Is this value retained in the country or repatriated? These questions are difficult to answer because standard trade data reports gross values of imports and exports and so the value added by individual countries within value chains remains obscured. This also has policy implications. For example trade deficits between the EU and China are much lower in terms of value added trade than they are when based on standard trade data (Koopman et al. 2012). At the level of individual economies, trade affects many crucial areas including value added, income and employment. Therefore, there is a need for better types of measurement which help to assess the participation of countries in GPN and the impacts of this engagement.

Whether participation of V4 countries in GPN has brought significant benefits and whether they exceed potential costs has been difficult to assess. So far, most research on this question has relied heavily on qualitative data from company interviews, often combined with trade and FDI data which make international comparisons difficult (Pavlínek et al. 2009; Pavlínek \& Ženka 2010; etc.). New data and indicators capturing trade within GPN should help to answer these questions. The main aim of this paper is to assess the position of V4 countries within the global production networks, assess the benefits and costs it has brought them and compare their situations. Firstly, the participation of V4 countries in GPN will be analysed with major attention paid to the share of domestic value added in exports, which is more useful for assessing the competitiveness of individual countries in the global economy and the effects of GPN participation. Secondly, the geographical extent of such GPN, particularly the origins of V4 countries imports and destination of final demand are evaluated. Thirdly, the situations in individual industries, mainly the differences between them, is assessed. The role of V4 countries in GPN will be mapped by using new data sources in particular the OECD-WTO Trade in Value Added (TiVA) combined with other statistics on national accounts over the period 1995 to 2011. This data complement mostly industry based studies on GPN in Central Europe and using them together allows deeper assessment of the benefits and costs of GPN participation. The secondary aim of this paper is to present how new data sources, especially the TiVA can help map the situation with respect to GPN operations.

The paper will proceed as follows. The next section ('Literature review') provides a brief review of the core literature related to global production networks. The third section ('Data and methodology') maps data sources used for measuring production fragmentation and GPN and the methods applied in the paper. Section 4 ('Results') uses these new data possibilities to examine the global integration of V4 economies in GPN. The final section ('Conclusion') offers a brief conclusion and highlights future research possibilities. 


\section{Literature review}

Moving production to other countries, the so called offshoring or internationalization of production, accelerated rapidly in the late 1970 s and was closely related to technological changes and liberalization. Increases in international production, especially the organisational fragmentation of production, contributed to the rapid expansion of world trade, which almost doubled in comparison with global GDP over the last three decades (WTO 2010). The fragmentation of production into many geographically separated steps, the so called 'slicing up' of the value chain (Dicken 2015) has been described by several terms. Global supply or commodity chains (Gereffi 1994), global value chains (Porter 1985) or global production networks (Coe et al. 2008) are the most common ones. In this paper, the GPN concept is used. Despite small differences between these terms, GPN framework gives more attention to spatial relations and embeddedness of GPN (Henderson et al. 2002; Smith et al. 2002; Yeung 2009). Coe et al. (2008) describe GPN as 'the circuit of interconnected functions, operations and transactions through which a specific commodity, good or service is produced, distributed and consumed.' According to Yeung and Coe (2015) global value chains and the so called GPN 1.0 give major attention to governance and other categories and underestimate the dynamics of these networks. Therefore, they do not provide a coherent theory. They came with the GPN 2.0 concept which focuses more on the reasons for differences in organisation and coordination of GPN, i.e. "why and how firms adopt diverse strategies to cope with different sets of competitive dynamics and risk environments" (Yeung \& Coe 2015: 53).

Value creation is fundamental for economic growth (Coe et al. 2008). In general, activities at the beginning and at the end of the value chain are those with the highest value added (such as design, R\&D, marketing) and their share in value added is increasing over time. There are large differences between individual GPN related to their governance which determine power relations between the actors in GPN (Gereffi et al. 2005). These are largely dependent on the industrial sectors, although even within the same industry different GPN types can exist, these modes can change over time and firms can be a part of several GPN with different government modes and at different positions (Blažek 2015; Yeung \& Coe 2015). The objective of firms, regions and countries is to improve their position within the GPN by creating possibilities to enhance the value added - the so-called upgrading (Henderson et al. 2002). Humphrey and Schmitz (2002) identify four basic types of upgrading: process, product, functional and chain upgrading. Since economic upgrading is mostly connected with firms, or countries. Barientos et al. (2011) introduced social upgrading, which refers to getting access to 'better' work, working conditions and rights at the level of individual workers. Governance modes and actorlevel strategic choices significantly affect the upgrading possibilities for firms, regions and even workers.

Organisational fragmentation and geographic dispersion of production has increased the efficiency and competiveness of firms. At the same time, the organisation of GPN in general follows the traditional determinants of comparative advantage. The effect of GPN on economies is highly dependent on the characteristics of the economies as well as the nature of GPN operations (Dicken 2015). Thus, the costs and benefits of trade are distributed unevenly between countries and also across social groups (Baldwin 2006). In order to be able to assess such impacts on countries, firstly there is a need to assess how deeply countries are integrated into GPN.

From the 1948 to 1989 Hungary, Poland and former Czechoslovakia were centrally planned economies with extensive growth, emphasis on heavy industry and most trade relations with other Eastern Bloc countries. In the early 1990s the disintegration of eco- 
nomic relations within COMECON (Council for Mutual Economic Assistance) led to the loss of eastern markets. At the same time products were uncompetitive for the Western markets and Visegrad countries witnessed big falls in GDP, often called the transformation crises. Nonetheless, during the transformation period, the Visegrad countries implemented neoliberal market-based reforms and attracted FDI and production activities mostly from EU15 countries (Drahokoupil 2009). The majority of FDI activity in manufacturing within V4 countries was directed towards exportoriented production taking advantage of the relatively skilled and cheap labour force, geographic location, investment incentives and subsequent integration into the EU (Pavlínek et al. 2009; Pavlínek \& Ženka 2016). Political and economic stability were also important factors (Myant \& Drahokoupil 2012). Despite the variations in transformation methods and their different pace in the region (e.g. Stern 1997; Roaf et al. 2014) the large FDI inflows have contributed to the development of a specific economic system which Nölke and Vliegenthart (2009) defined as dependent market economies. They are characterized by large manufacturing exports through producer-driven networks (Myant \& Drahokoupil 2012). The attitude towards FDI inflows also varied, however, by 2000 all Visegrad countries offered investment incentives (Drahokoupil 2009). FDI inflows were mostly directed towards services (particularly the banking sector to serve to domestic market) and manufacturing leading to big role of foreign capital and TNCs in these economies. The impact of this investment on employment, economic growth on local companies differs across industries and regions (Pavlínek 2004; Pavlínek \& Žížalová 2014; Dicken 2015). Particularly due to the large foreign investment, exports of goods and services as a percentage of GDP rose from over $40 \%$ in 1995 , to around $90 \%$ in Hungary and Slovakia, $83 \%$ in Czechia and $47 \%$ in Poland in 2015. Furthermore, manufacturing continues to be very important in V4 economies and despite deindustrialization in the major- ity of developed countries, the share has not declined much in the region, in Czechia and Hungary it has actually risen. Employment in manufacturing exceeds $30 \%$ and its share of GDP ranges between 19\% in Poland and $27 \%$ in Czechia and is the highest in EU countries (World Bank 2016).

Automotive industry is the leading industry in Central Europe. V4 countries have been integrated into the European automotive industry due to their comparative advantage in assembly and labour-intensive manufacturing (Humphrey et. al. 2000) and V4 countries now produce almost 20\% of European passenger cars (OICA 2016). Therefore, most studies on GPN in Central Europe (CE) focused on this industry. In the automotive industry, there is a high degree of vertical disintegration organized by large lead assembly firms (Sturgeon et al. 2008). The findings reveal that local suppliers became integrated into the production network and the embeddedness of TNCs has been increasing over time (Domanski \& Gwosdz 2009; Jürgens \& Krzywdzinski 2009).Upgrading occurred in both domestic and foreign-owned firms (Domanski \& Gwozd 2009; Sass \& Szalavetz 2014), though this process was highly selective and very uneven (Pavlínek \& Ženka 2010). In addition, there is limited evidence of social upgrading (Fortwengel 2011). Since exports in V4 countries are dominated by foreign companies, there is a potential of value transfer to the home economies of foreign firms due to value profit shifting strategies (Dishinger et. al. 2014). In a recent paper Pavlínek and Ženka (2016) found that higher tier foreign owned companies create and capture more value than lower tier domestic firms.

Most of the research undertaken so far was based on case studies which do not allow for comparisons. Furthermore, the findings are in most cases limited to the automotive industry and cannot be generalized due to sectoral- and firm-specifc differences. Other industries in V4 countries were mapped only partially, such as the clothing industry in Slovakia (Smith et al. 2014) and the electronics industry in Hungary (Plank \& Staritz 
2013; Sass \& Szalavets 2014). Therefore, in order to assess the costs and benefits associated with participation in GPN in V4 countries and their position in the global economy, firstly the extent of such participation needs to be assessed.

\section{Data and methodology}

The growth in world trade over the past three decades has in part been caused by the organisational fragmentation and geographic dispersion of production activities. As a result, observed trade flows increased by $32 \%$ in 2011 due to multiple counting according to the TiVA data (OECD-WTO 2016). International trade data can therefore give a distorted picture of the impact of exports on domestic economies. Moreover, trade data do not distinguish between industries that add value, since firms also incorporate domestic inputs from other industries of the economy. This is relevant with respect to the competitiveness of nations and the location of their activities in the value chain. Measuring comparative advantage of nations in products or industries based on trade data might thus be misleading.

There are three types of international trade data that are being used to map the GPN: highly detailed product trade statistics to identify trade with parts and components (Yeats 1998), processing trade based on customs data (Feenstra et al. 1998; Egger \& Egger 2005). This paper is based on the third and most widely employed method - input-output tables (Hummels et al. 2011; Koopman et al. 2008). Apart from trade data, company-level analyses have been widespread in order to map GPN, which either rely on qualitative surveys or firm-level trade data (Wang \& Lee 2007; Pavlínek \& Ženka 2014), though, differences in applied methodology generally make international comparison difficult. For a more detailed description of measuring GPN see Amador and Cabral (2013).

Measuring the value-added content of trade at a global level requires international input-output tables which are avail- able only for some countries, e.g. IDE-JETRO, UNCTAD-Eora GPN Database, WIOD and GTAP. In this paper the Trade in Value Added (TiVA) database, a common project by OECD and WTO, has been used. TiVA contains statistics for 61 economies for the years 1995, 2000, 2005, and 2008-2011 broken down into industrial sectors and it encompasses over $95 \%$ of global output and $90 \%$ of international trade. The measurement relates to industries' activity rather than to products, the source data are based on activities and production of industries. There are differences between the input-output datasets, but those were found to be relatively small (see Timmer et al. 2015). TiVA data have become widely used to explore the position of countries in GPN (De Backer \& Miroudot 2013; Ferrarini \& Hummels 2014).

TiVA datasets also suffer from several limitations. Based on production assumption, for a given industry all firms allocated to that industry use the same goods and services to produce the same outputs. Moreover, it is assumed that the share of intermediate imports in products consumed directly and those destined for exports is the same (the proportionality assumption). Particularly in countries with a high level of 'processing trade' such as China this can be problematic (Koopman et al. 2008; Vlčková 2015) and the latest version of TiVA (December 2016), input-output tables for China differentiate between exporting firms and production intended only for domestic consumption, the numbers have changed considerably from the earlier years. Also in developed countries, there is a large heterogeneity between firms and thus estimates of the share of foreign content in exports can be biased downwards.

One of the basic measures of the economic integration of different national economies in GPN is the participation index. This unified indicator, which incorporates previous measures of vertical specialization and valueadded trade has been developed by Koopman et al. (2010). The participation index consists of two parts. The backward participation index measures the foreign value 
added embodied in gross exports (the share of foreign inputs in exports - x-axis in Fig.1). The forward participation index indicates the share of domestically produced inputs used in third countries' exports ( $y$-axis in Fig. 1). The participation index is a sum of the backward and forward participation index. The remaining part of gross exports are domestic value added exports used in the country of export for direct consumption (destination of final demand). These measures illustrate how much value is generated in the economy and can be broken down into various industries.

In this paper data are mostly presented in the form of simple tables and graphs. The only exception is the application of network analysis. In terms of GPN the network analysis is often used to map the vertical trade, specifically the direction and intensity of network relations between countries (Ferrarini 2011). Here, network analysis is only used as a visualization technique for assessing similarities between countries based on their patterns of revealed comparative advantage (RCA) in gross exports and value added exports (Hidalgo et al. 2008). The revealed relatedness between countries (their RCA), is measured by the Jaccard similarity index (sometimes the Dice measure is used, see Novotný \& Cheshire 2012). The resulting matrix of similarity values is difficult to interpret, therefore Cytospace open source software was used to visualize these relations. The layout of a network is chosen so that the nodes with higher relatedness are closer than those with lower values of relatedness presenting the position of individual countries.

\section{Results}

The main objective of this paper to assess the position of $\mathrm{V} 4$ countries within the global production networks and compare them. The assessment is based mostly on various types of TiVA data, combined with other indicators to complement existing mostly industry-level research. This will be undertaken in several areas. The extent of participation in GPN (the type of this participation and the position within GPN) is elaborated upon in the first subsection ('Participation in global production network') including the costs and benefits associated with the integration of V4 countries. The origins of V4 countries imports and destinations of final demand will be evaluated in the second subsection ('Geographic extent of global production networks'). In the third subsection ('The situation in individual industries') the situation in individual industries is mapped including revealed comparative advantage in industries in terms of value added.

\section{Participation in global production networks}

The rise in exports in V4 countries during the last two decades was driven by FDI inflows which were crucial for economic restructuring, though the attitudes toward FDI in the early stages of transformation differed among the Visegrad countries. Rising exports do not necessarily mean that these economies are becoming more competitive. There is a big difference between gross exports and domestic value-added exports (VA exports forthwith), since exports also contain value added created in other countries. Thus, the export shares in value added terms are more useful in assessing countries' competitiveness in the global economy as well as the effects of GPN participation on economies. Domestic value-added exports may be found by subtracting foreign value-added (which is created in other countries, imported and enters the exports of the country) from the gross exports of a particular country. There are significant differences between countries in terms of value added exports and gross exports and these depend on the country's engagement in GPN and on the types of activities of the production process that they take part in.

In general, small open economies source more inputs from abroad and overall have greater participation in GPN. The participation index is thus high for all V4 countries and exports which are not part of GPN are relatively low. Slovakia and Hungary belong 
to the countries with the highest GPN participation with over $73 \%$ of gross exports (only in Luxemburg and Taiwan is it higher). In Hungary, this is likely related to an open attitude towards foreign capital already present in the 1980s, Slovakia is the smallest economy in Visegrad. High participation in GPN does not necessarily mean higher gains. In terms of net value added from participation in GPN, the higher is the forward index compared to the backward index, the more a country is exporting domestic value-added than it is importing foreign value added within GPN. This is the case of the United States, which is capturing value thanks to the fact that it is involved in upstream activities like design, R\&D and branding with high VA, as well as exporters of primary commodities which are present in most GPN such as Russia and Saudi Arabia (Fig 1).

As Table 1 illustrates there has been a significant increase in exports from Visegrad countries over the period as well as in the participation index. The backward index has risen more steeply than the forward index. This has been associated with the large FDI inflows leading to production for exports and the rise of intermediate inputs both in imports and exports. Despite traditionally producing final products, Visegrad countries started producing intermediates in the 1990s because their final products were uncompetitive on Western markets. Intermediates now account for over $70 \%$ of all imports $(65 \%$ in Poland) and almost $60 \%$ of all exports. Backward linkages are higher in manufacturing than services, which are in general less tradable and less represented in V4 exports. Over $60 \%$ of Visegrad exports are in machinery, transportation and electronics. After the steep decline of the machinery and automotive exports in CE countries in the early 1990s there was a steady increase since the mid-1990s. This has been associated with

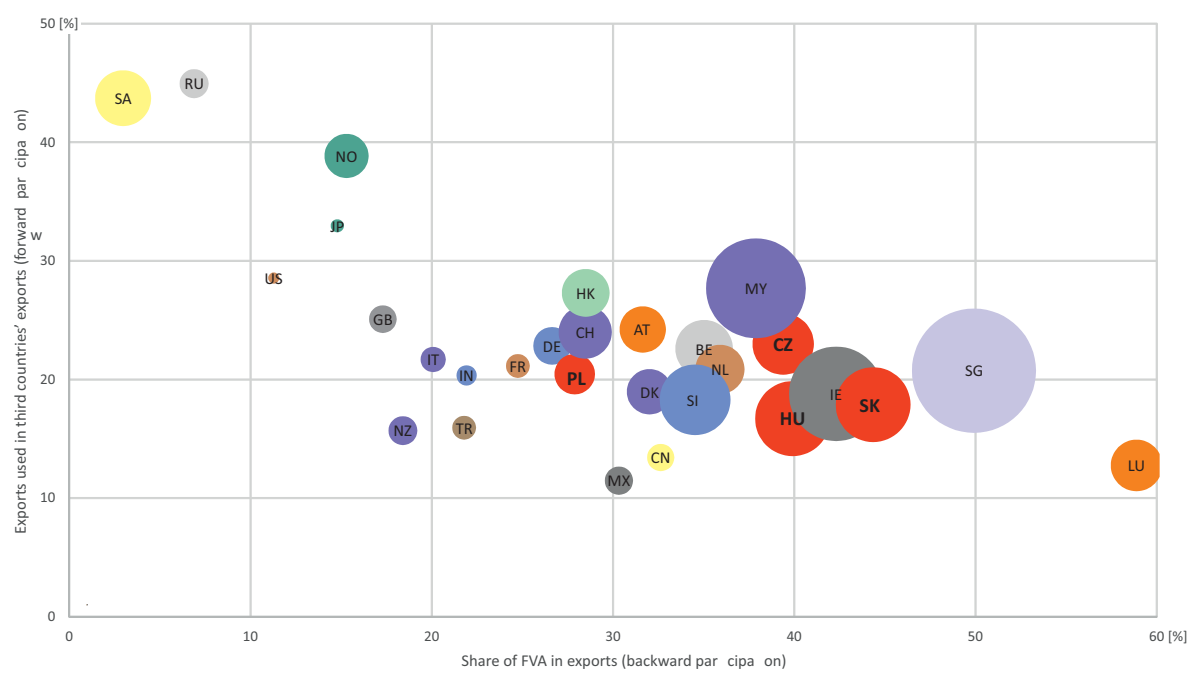

Note: Size of the circles indicates the share of exports to GDP

Country abbreviations: AT - Austria, BE - Belgium, CN - China, CH - Switzerland, CZ - Czech Republic, DE - Germany, DK - Denmark, FR - France, GB - Great Britain, HK - Hong Kong, HU - Hungary, IE - Ireland, IN - India, IT - Italy, JP - Japan, LU - Luxembourg, MY - Malaysia, MX - Mexico, NL - Netherlands, NZ - New Zealand, RU - Russia, TR - Turkey, SA - Saudi Arabia, SK - Slovakia, SG - Singapore

Figure 1. Position of $\mathrm{V} 4$ countries in GPN in 2011

Source: based on data from OECD-WTO (2015), World Bank (2016). 
Table 1. Exports and GPN participation in V4 countries

\begin{tabular}{|l|c|c|c|c|c|c|c|c|}
\hline & \multicolumn{2}{|c|}{$\begin{array}{c}\text { Gross exports } \\
\text { [million USD] }\end{array}$} & \multicolumn{2}{c|}{ Participation index } & \multicolumn{2}{c|}{$\begin{array}{c}\text { Participation index - } \\
\text { backward }\end{array}$} & \multicolumn{2}{c|}{$\begin{array}{c}\text { Participation index - } \\
\text { forward }\end{array}$} \\
\hline Year & 1995 & 2011 & 1995 & 2011 & 1995 & 2011 & 1995 & 2011 \\
\hline Czechia & 27,485 & 153,596 & 50.7 & 71.6 & 30.6 & 45.3 & 20.1 & 26.3 \\
Hungary & 20,072 & 106,919 & 45.9 & 73.0 & 29.9 & 48.7 & 16.1 & 24.4 \\
Poland & 30,934 & 213,576 & 35.3 & 58.0 & 16.1 & 32.4 & 19.2 & 25.6 \\
Slovakia & 10,022 & 70,232 & 53.6 & 74.7 & 31.9 & 46.8 & 21.7 & 27.9 \\
\hline
\end{tabular}

Source: OECD-WTO, 2016.

the entry of TNCs which focused mainly on the production of inter-mediates for export (Myant \& Drahokoupil 2013). Heavy industry, particularly machinery, metallurgy and the chemical industry, greatly outweighed light industry in socialist countries. It was particularly developed in Czechia, whereas Hungary had a stronger tradition in electronics compared to the other Visegrad countries. Machinery, transportation and electronics belong to the most fragmented industries (see subsection 'The situation in individual industries' - 4.3) and explain the large integration of Visegrad countries into GPN. Whilst the situation is very similar in Czechia, Hungary and Slovakia, Poland is slightly different. The role of exports and participation is lower there due to its bigger market (its population is almost 7 times higher than that of Slovakia). Furthermore, industrial structure is also different. Poland is among the major exporters of the food products in the EU, which belongs to industries with the lowest share of fragmentation and foreign inputs.

The ratio of backward to forward participation index between 1995 and 2011 decreased in most countries of the world due to the increasing organisational fragmentation and geographic dispersion of the production process. In general, the offshoring of production by developed countries to emerging economies (including the $\mathrm{V} 4$ ) is associated with the rise in the service sector and activities with higher value added in developed countries (Baldwin 2006) and is also demonstrated by the large decrease in the share of manu- facturing to GDP. In Visegrad countries the role of manufacturing has stagnated or even risen over the last two decades. The big role of manufacturing dependent on foreign inputs and less important role of services (see 4.3) is one of the reasons why in these countries the ratio of backward to forward linkages belong to the lowest among all examined countries (with the exception of Poland), only countries such as Luxemburg, Ireland and Mexico have lower ratios. Nonetheless, this ratio has been relatively stable over the period. Only Poland witnessed a significant decline (between 1995 and 2000) of the ratio confirming its later integration into GPN (Jakab et al. 2001).

Linking into GPN can boost growth in industries and increase production and employment. Forward linkages are especially useful in industries where a country does not have comparative advantage in producing the final products but has the locational advantages in production of its intermediate products such as low cost labour or possession of particular skills or factors (OECD 2013). This was the case of CE countries mainly in the 1990s. Backward linkages on the other hand, can improve the cost competitiveness of gross exports. The dependence on FDI has had positive as well as negative effects on these economies which differ based on motives for investment, local conditions as well as the area under research (e.g. productivity, employment). Overall, the degree of embeddedness of TNCs in the local economy is of key importance for their competitiveness and upgrading. In V4 countries the link- 
ages between TNCs and regional economies were limited in the 1990s (Pavlínek 2004). Nonetheless, since the turn of the century foreign manufacturing companies became more embedded, although there are differences between industries (see subsection 'The situation in individual industries'). The big role of TNCs in these economies is confirmed by the fact that inward FDI stock account for around $60 \%$ of GDP (40\% in Poland). Moreover, foreign companies account for between $48 \%$ to $68 \%$ of value added and $35 \%$ to $50 \%$ of employees in manufacturing, with the lowest numbers in Poland and the highest in Hungary (OECD 2016).

The economic impact of GPN is not only related to value creation. It is also about the control of value added and whether the value is captured in the country. Dependence on TNCs and foreign capital significantly raised exports. However, foreign companies affect what and how something is being produced (the decisions are often made outside these economies) and they capture more value than domestic ones (Pavlínek \& Ženka 2016). Thus the value control is low in many areas and since most of this investment is already generating large profits, leading to large value transfers abroad this has recently raised also policy concerns in Visegrad. This is not only related to profit repatriations but also to various forms of other profit shifting strategies such as transfer pricing which leads to high levels of tax avoidance (Dishinger et al. 2014). Some Visegrad countries have introduced stricter reporting regimes for TNCs or sectoral taxes in highly regulated industries, although some of these measures (such as sectoral taxes) are likely to be reflected in higher prices for customers.

One of the ways to increase value creation, control and also capture is to upgrade, referring particularly to higher value added activities. FDI inflows have contributed to technological development since foreign owned companies are more efficient than domestic ones (Peter et al. 2012) although, the evidence in terms of spillovers to local companies, there are big variations (e.g. Plank \& Staritz
2013; Pavlínek \& Žížalová 2014). Product and process upgrading dominated in Visegrad, though unctional upgrading, which increases the value the most is rather rare (Pavlínek \& Ženka 2010; Micek 2015). Further, little attention has been paid to downgrading which has also been happening e.g. during foreign takeovers of local firms. The evidence relating to social upgrading is mixed and this is related mostly to low wages compared to Western European countries. There are big pressures to raise wages, especially from Czech unions due to currently lowest level of unemployment in Czechia among all EU states (3.8\% in September 2017). However, wages need to reflect labour productivity and this has been still much lower than the EU average (European Commission 2016). Upgrading and position in GPN are to large extent dependent on absorptive capacity of local firms (Kim \& Ernst 2002), relations with lead firms and managers as well as external factors. The strategies of firms and their position in GPN evolve. Firms can also have different positions in different GPN, which cannot be captured by existing governance and upgrading types (Blažek 2015; Coe \& Yeung 2015).

More capable domestic firms could help decrease the dependence on foreign capital and increase the value creation, control and capture (Henderson et al. 2002; Coe et al. 2004). Such companies among others also source more inputs locally. Domesticallyowned firms are often disadvantaged since incentives (such as tax holidays and support for new jobs) are more often exploited by large foreign companies. In addition, foreign firms often poach highly qualified people from local companies, which trained them and this hinders their innovation capabilities. In general, the entrepreneurship in Visegrad countries is low due to its 40 year old communist history and the local firms' overall ambitions are often small focusing on keeping the status quo (TAČR 2015). The investment of domestic companies abroad is significantly lower (FDI outward stock is below 5\% of GDP in Poland and Slovakia, 10\% in Czechia and almost 30\% in Hungary - OECD 2016) and 
this investment is usually still at an early stage with low profits, although several successful firms internationalizing their operation from an early start - so called born globals such as Wizz Air, Linet and Eset. Such (lead) companies would also raise the forward participation in GPN. Favourable business environment, supporting innovation and entrepreneurship would increase the benefits associated with participation in global production networks for the Visegrad countries.

\section{Geographic extent of global production networks}

Geographic proximity and economic integration are the major factors affecting the structure of export destinations (Amador \& Cabral 2013). In this subsection, the origins of inputs in V4 countries' exports and the final destinations of the domestic value added originating in V4 countries are explored in the context their communist history and subsequent transformation.

As the exports of V4 countries have increased over the period, so have the export destinations and countries of origin of V4 imports slightly changed. Over the 1990s the role of COMECON in Visegrad countries' trade was gradually decreasing whereas that of Western Europe has become more important, particularly after their EU accession. In Table 2 countries located upstream and downstream in the GPN are included for the year 2011. In 2011 most of the foreign value added (FVA) embodied in exports came from Germany, whereas in 1995 most of the FVA originated from the Russian Federation (22\%). The share of the United States in FVA exports of the Visegrad declined slightly, and the biggest relative increase was in case of China (from 0\% to 5\%), Korea (from 1\% to 3\%) and Japan (from 2\% to 4\%). Apart from tax havens such as the Netherlands and Luxemburg, Germany is the main investor and Visegrad economies are closely linked to its GPN. The bigger role of Korea and Japan corresponds with the rise in FDI inflows from these countries over the period. The origin of FVA is also dependent on the origin of TNCs in Visegrad countries, e.g. the bigger role of Korea in Slovakian exports is due to the presence of Kia Motors. The origin of investing TNCs is also relevant due to the variations in their behavior. For example, Japanese and Korean automotive firms in Czechia exclude domestic firms from production networks and rely on foreign sourcing (Pavlínek \& Žížalová 2014).

Within V4 countries there was an increase in the FVA from Hungary and especially Poland and a decrease of FVA from Czechia and Slovakia. This might signify that Poland and Hungary have become more linked to GPN (confirmed by the increasing participation index - see Tab. 1). However, this might also mean that Czechia and Slovakia are exporting less domestic VA, or that they changed their position within the GPN (either are not in the same GPN or are more often located downstream from Hungary and Poland). At least within the automotive industry, Czechia exports lower shares of high value-added products (engines etc.) than Poland and Hungary. This is because high value-added products are not exported, they are used for the assembly of passenger cars in Czechia (Pavlínek et al. 2009).

Destinations of V4 countries exports and value added (located downstream in GPN) changed slightly over the period. For example, exports to the United States, Russian Federation, Austria and Germany decreased relatively by a third, and even more in the case of Japan. On the other hand the biggest increase was in gross exports to Poland, China and Spain (from 1\% to 3\%) among important export destinations. TiVA data also enable one to compare where domestic value added exports of V4 countries go for final demand, revealing the trends that go far beyond the possibilities of traditional trade data. Since 1995, there has been an increase in exports to emerging economies. This can only signify that these economies are one step lower down the value chain in terms of their activities (downstream). Identifying the countries of final demand for products containing value added originating from V4 countries enables 
Table 2. Origination and destination of value added in V4 countries (2011)

\begin{tabular}{|c|c|c|c|c|}
\hline & \multicolumn{2}{|c|}{ Upstream } & \multicolumn{2}{|c|}{ Downstream } \\
\hline & $\begin{array}{l}\text { origin of FVA in V4 } \\
\text { countries' exports [\%] }\end{array}$ & $\begin{array}{c}\text { share of imports } \\
{[\%]}\end{array}$ & $\begin{array}{l}\text { final destination of VA } \\
\text { from } V 4 \text { countries [\%] }\end{array}$ & $\begin{array}{c}\text { share of gross exports } \\
{[\%]}\end{array}$ \\
\hline OECD & 67 & 70 & 75 & 79 \\
\hline EU28 & 54 & 63 & 63 & 72 \\
\hline EU15 & 43 & 47 & 50 & 55 \\
\hline Germany & 19 & 22 & 19 & 24 \\
\hline Italy & 5 & 5 & 6 & 6 \\
\hline France & 4 & 4 & 6 & 6 \\
\hline United Kingdom & 3 & 3 & 6 & 6 \\
\hline Spain & 2 & 2 & 3 & 3 \\
\hline Austria & 3 & 3 & 3 & 4 \\
\hline Netherlands & 2 & 2 & 1 & 1 \\
\hline Czechia & 2 & 4 & 3 & 4 \\
\hline Poland & 3 & 4 & 2 & 3 \\
\hline Hungary & 1 & 2 & 1 & 2 \\
\hline Slovakia & 2 & 3 & 2 & 3 \\
\hline Russian Federation & 12 & 11 & 5 & 5 \\
\hline United States & 5 & 3 & 6 & 4 \\
\hline China & 7 & 7 & 3 & 3 \\
\hline Korea & 2 & 1 & 1 & 1 \\
\hline Japan & 3 & 1 & 1 & 1 \\
\hline
\end{tabular}

Source: OECD-WTO, 2016.

one to explore it. This is also highly relevant for trade policies, since V4 countries might have weak trade relationships with countries where consumers of final goods and services are located. In Table 2 there is evidence that Germany and the Netherlands are less important as countries of final demand whereas more exports go to the United States indirectly. The United States is the only country where indirect exports (embodied in intermediate inputs) are more important than direct gross exports. Most of these indirect exports are in services that are often located upstream in the GPN. These include wholesale and retail trade, transportation and storage or financial intermediation. On the other hand, if we look at bilateral trade relations between individual Visegrad countries, the gross exports are almost twice as high as the VA in final demand of respective country (e.g. exports from Czechia to Slovakia are two times higher than Czech domestic VA consumed in Slovakia). This signifies that they export to the neighboring countries mostly intermediates which are processed and then further exported to a third country. This demonstrates that these countries are linked to each other in regional value chains. Similar situations are also found with Germany, Austria, Slovenia and Ireland.

In general, most of the FVA in exports of V4 countries originates in developed countries and most of the V4 countries value added is destined for developed countries, although 
Germany, for example, is to a large extent a destination of intermediate inputs. This confirms the importance of linkages within these economies and the existence of regional value chains. Despite a recent claim by Baldwin and Lopez-Gonzalez (2015) that global value chains are not global but regional, Los et al. (2015) found by using WIOD data that value chains became increasingly more internationally fragmented between 1995 and 2011 and that global fragmentation progressed faster than regional. The TiVA data also confirm that networks are getting increasingly more global rather than regional with Europe being the only region where intra-regional FVA still exceeds the extra-regional FVA (likely affected by the existence of an internal market). The share of FVA from the EU in exports of V4 countries increased by $1 \%$, however due to the decreasing role of Russia the regional FVA from Europe decreased from $77 \%$ to $69 \%$. The rising share of extraregional FVA is highly relevant for V4 countries, since it proves that the need to compete with countries from other parts of the world is likely to increase.

\section{The situation in individual industries}

The participation in GPN and the costs and benefits associated with it differ between industries and are strongly spatially variegated. This is related to the variations in the extent of organizational fragmentation between industries as well as the difference in governance types/firm-specific strategies (see Gereffi et al. 2005; Yeung \& Coe 2015). The export structure of V4 countries is very similar. Four industries account for over $50 \%$ of exports in V4 countries and these are: 'Chemicals and non-metallic mineral products', 'Basic metals and fabricated metal products', 'Electrical and optical equipment' and 'Transport equipment'. The last two sectors have increased their share among exports the most over the period from around $5 \%$ to $15-20 \%$ and they are the leading sectors in gross exports. 'Transport equipment' sector also attracted the highest FDI inflows (after financial intermediation) over the period (OECD 2016).

'Transport equipment' and 'Electrical and optical equipment' industries are those most organisationally fragmented and spatially dispersed, therefore V4 countries have a high export share, significant participation in GPN and a high share of FVA in their exports. On the other hand in 'Chemicals and non-metallic mineral products' and 'Basic metals and fabricated metal products', the shares of gross exports and value added export of individual countries are quite similar (Fig. 2). Among V4 countries Poland has a lower FVA content of exports in most industries, which is largely attributable to its larger market. On the other hand both Hungary and Slovakia have the highest FVA in the majority of industries. Foreign value added of exports only shows the backward linkages. Domestically produced inputs are also used in third countries' exports (the forward linkages). Forward linkages are always higher in 'Mining and quarrying' which is located at the beginning of most GPN and in the service sector the forward linkages are only slightly lower than backward linkages.

For competitiveness and upgrading of firms, the degree of embeddedness of TNC in local economies is crucial (Pavlínek 2004). Within the Visegrad countries the automotive industry has become more embedded (functionally connected) than the electronics industry. In the electronics industry the FVA in exports between 1995 and 2011 increased much more in all Visegrad countries (from around 40 to 60), whereas FVA in automotive exports remained stable in Czechia and Slovakia (reaching 55 in CZ and 60 in SK) (OECD-WTO 2016).

This is related to the differences between these sectors. The automotive industry has more expensive intercontinental shipping, widespread JIT regimes and is under greater political pressure (Sturgeon et al. 2008) and last but not least has a bigger tradition in Central Europe (particularly in Czechia). Skoda is a good example of strategic coupling in automotive industry - a situation 


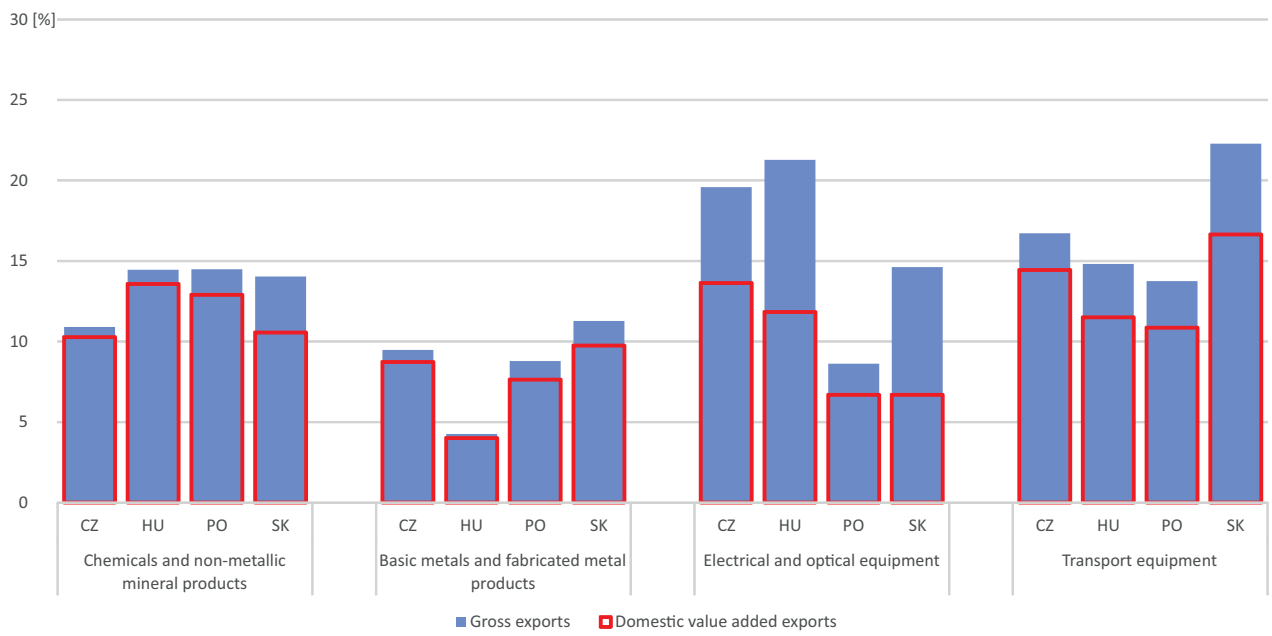

Figure 2. Share of selected industries on gross exports (GE) and domestic value added exports (DVA) in V4 countries

Source: based on data from OECD-WTO (2016).

when regional assets complement the strategic needs of lead firms in GPN (Coe et al., 2004). This situation differs from greenfield investment, since local suppliers are already present. However, in the automotive production networks increasing globalization has led to the decreasing role of domestic suppliers due to centralized sourcing strategies of TNCs (Humphrey \& Memedovic 2003). Domestic firms are mostly tier 2 or tier 3. Further, most capable domestic firms were taken over by foreign firms during transformation (in all industries) and several acquired companies witnessed downgrading (Pavlínek 2012). Nonetheless, according to Drahokoupil (2009) crowding out effect of FDI were to certain extent an inseparable part of the political and economic transformation in Central Europe. Despite geographic proximity and flexibility, domestic firms are often disadvantageous due to lower quality, smaller size unable to deliver in large quantities and also pressure from lower cost locations which hinders upgrading (Pavlínek \& Žížalová 2014). The electronics industry, on the other hand is associated with lower FDI inflows, lower local linkages accompanied by bigger 'footlooseness' of this industry, much higher for- eign backward linkages and even bigger role of foreign companies (Sass 2015). Germany is the major source of inputs in automotive industry in V4, although it has less significant role in electronics, where China has almost similar position.

Goods account for about $80 \%$ of international trade, however, this number does not take into account the role of services in creating goods, which include many upstream and downstream activities like design, R\&D, branding and marketing which account for a large share of value added (Mudambi 2008; Sjøholt \& Vatne 2012). TiVA data enable one to estimate the contribution made by the service sector in total exports. Between 1995 and 2011 the share of services value-added exports increased globally and now reaches around $60 \%$ of all exports in developed countries (the EU28 average was 58\% in 2011) and around $40 \%$ in developing countries, with the exception of India which is an important service provider. In V4 countries the service VA in exports reach only around 50\% (see fig 3) and with insignificant changes over the observed period. Furthermore, over 40\% of this services value added (in Poland one third) is created in other countries. Manufac- 


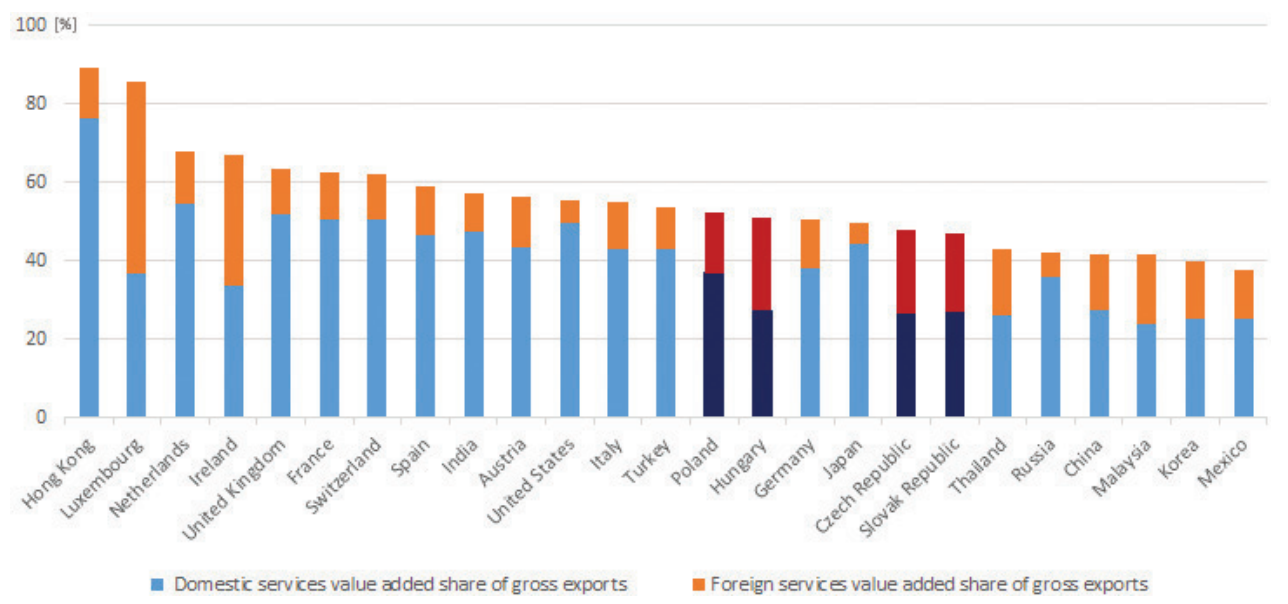

Figure 3. Services value added embodied in gross exports in 2011

Source: based on data from OECD-WTO (2016).

turing exports of V4 countries embodied 35\% of services in 2011 with almost half of it originating from foreign countries such as Germany, the United States, France and Italy.

Most of the rents from GPN originate from services such as R\&D, design and marketing rather than basic manufacturing. This is the main challenge faced by the V4 countries. The majority of the FDI inflows to V4 countries were to the service sector, although particularly to the banking sector serving the home market. Also some service activities have been offshored to these economies such as the shared service centers (Aggarwall et al. 2008), even though this investment has only made a partial contribution to the development of the knowledge based economy, and was limited regarding employment creation (Capik \& Drahokoupil 2011). Despite the rising share of tertiary educated people over the period, particularly in social science, it was not reflected in the service share of exports. FDI incentives provided by Visegrad governments in the region now stress high-value added activities, though in reality low-skilled operations are still largely supported. Recently, several new research centers of TNCs have started to be built in the region. Hence, the situation might be changing and this requires detailed research. Over- all, large heterogeneity of firms makes generalizations even within industries unsuitable. More preferably domestic companies should be categorized into groups based on their capabilities and FDI effects assessed across these groups.

In order to further compare the V4 countries in terms of their industrial specialization the revealed comparative advantage, an index proposed by Balassa (1965) is used. It measures the relative advantage or disadvantage of a certain country exporting a certain type of good. Traditionally, it has been computed based on gross exports. Therefore, the biggest disadvantage of RCA was that it did not take into account specific factors which are the source of comparative advantage, e.g. that exported goods include inputs from several industries and inputs produced in other countries. Both of these limitations are overcome when using trade in value added data, though, only highly aggregated sectoral data are available for such calculations.

In manufactured products Czechia, Hungary and Slovakia have the biggest revealed comparative advantage (in gross and VA exports) in 'Motor vehicles, trailers and semitrailers' and Poland in 'Wood and products of wood and cork'. Other industries with RCA are 'Fabricated metal products' and 'Rub- 
ber and plastics products', both of which are common supplying industries of the automotive industry. The differences between gross exports RCA and value added exports RCA in V4 countries are relatively small. However, the situation has changed significantly since 1995. Except for the case of Poland, the industries with RCA were different: 'Other nonmetallic mineral products' in Czechia, 'Food products, beverages and tobacco' in Hungary and 'Basic metals' in Slovakia.

In order to compare whether and how V4 countries differ based on their revealed comparative advantage and where they are located in the 'industry space' among major industrial exporters a network analysis is used. This network is thus a visualization technique which enables one to explore similarities between countries. The closer the nodes (countries) are to one another, the more similarities they have in terms of their RCA in industries. Four figures are presented to explore the differences between countries based on RCA in domestic value added exports (DVA) and gross exports (GE) in 1995 and 2011 (see Fig. 4 ). V4 countries are marked in red, Germany as the main trade partner in blue. Over time several countries are moving further apart, particularly exporters of primary commodities such as Saudi Arabia, Norway or Russian Federation. However, all V4 countries are located close to one another in the 'industry space' and there are only slight changes over time. This confirms very similar industrial orientation of these CE countries. In general, they are located close to many other mostly European countries. Especially two other Central and Eastern European countries are very similar in terms of their industrial orientation - Romania and Slovenia. Both of them have strong RCA in Rubber and Plastics and Wood products.

The position of Germany is of great interest as in 1995 Germany was further apart from other countries in both figures, whereas in 2011 Germany was located closer to other countries, especially to V4 countries. This confirms that not only Visegrad countries have become more similar in their industrial struc- tures, but they have also become more similar to Germany (particularly Czechia). Germany's RCA is especially in Motor vehicles, trailers and semi-trailers, Fabricated metal products or Rubber and plastics products. The increasing similarities between the Visegrad Group and Germany also confirm the growing integration into German led GPN, (OECD 2014) which further affects upgrading possibilities and the position of these economies in GPN. Cluster analysis was also performed to proof that the results of network analysis is not just random distribution. Czechia, Slovakia, Hungary, Poland and Germany merged into one cluster confirming the same results as the 'industry space' (Fig. 5).

In relation to the challenges associated with the current fast pace of technological changes (so called fourth industrial revolution) the lack of technological progress is a big problem. Digitalization, robotisation, automatisation and shared economy are likely to affect all areas. This brings not only the risks of lower employment and/or relocations for the Visegrad countries since automatisation requires less (mostly low-skilled) employees, but also more widespread carsharing can lower demand and affect those economies highly dependent on the automotive industry (e.g. in Czechia the automotive industry including supplying industries accounts for almost a fifth of GDP).

\section{Conclusion}

The aim of this paper is to assess the position of V4 countries in GPN and the costs and benefits, which are associated with it. By using country-level data from all industries derived from input-output models (TiVA), combined with other data and studies this paper overcomes the major limitation of existing research which is based on case studies of individual industries (especially the automotive industry) and does not enable one to assess the situation at the country level.

V4 countries are small open economies (with the exception of Poland), which have become integrated into the highly complex 

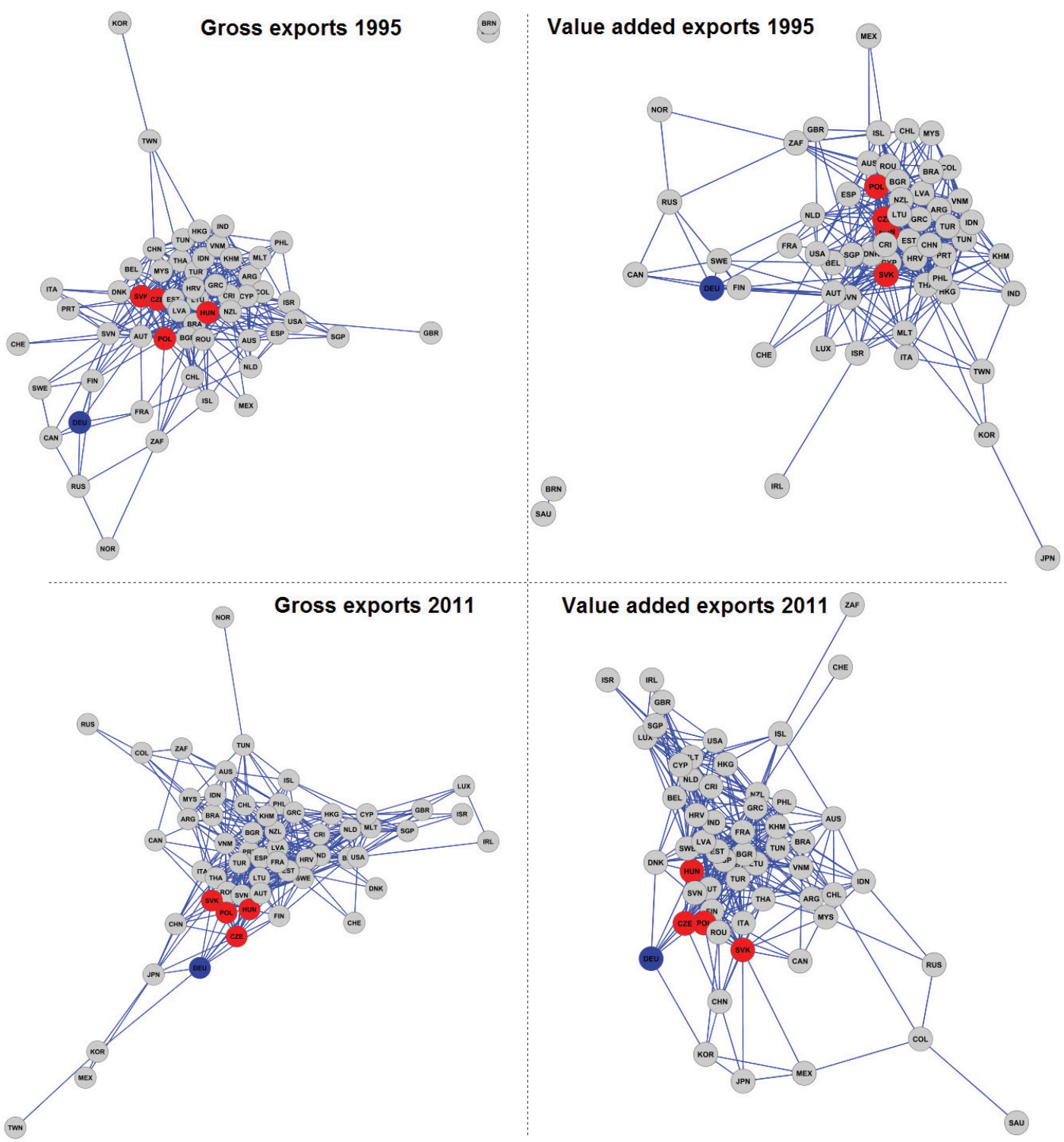

Country abbreviations: ARG - Argentina, AUT - Austria, BEL - Belgium, BGR - Bulgaria, BRA - Brazil, BRN - Brunei Darussalam, CAN - Canada, CHE - Switzerland, CHL - Chile, CHN - China, COL - Colombia, CRI - Costa Rica, CYP - Cyprus, CZE - Czech Republic, DEU - Germany, DNK - Denmark, ESP - Spain, EST - Estonia, FIN - Finland, FRA - France, GBR - Great Britain, GRC - Greece, HKG - Hong Kong, HRV - Croatia, HUN - Hungary, IDN - Indonesia, IND - India, IRL - Ireland, ISL - Island, ISR - Israel, ITA - Italy, JPN - Japan, KHM - Cambodia, KOR - South Korea, LTU - Lithuania, LVA - Latvia, LUX - Luxembourg, MEX - Mexico, MLT - Malta, MYS - Malaysia, NLD - Netherlands, PHL - Philippines, POL - Poland, ROU - Romania, RUS - Russia, SAU - Saudi Arabia, SGP - Singapore, SWE - Sweden, SVK - Slovakia, SVN - Slovenia, THA - Thailand, TWN - Taiwan, TUN - Tunisia, TUR - Turkey, USA - United States, ZAF - South Africa

Figure 4. Industry space based on revealed comparative advantage (RCA) in gross exports and value added exports 


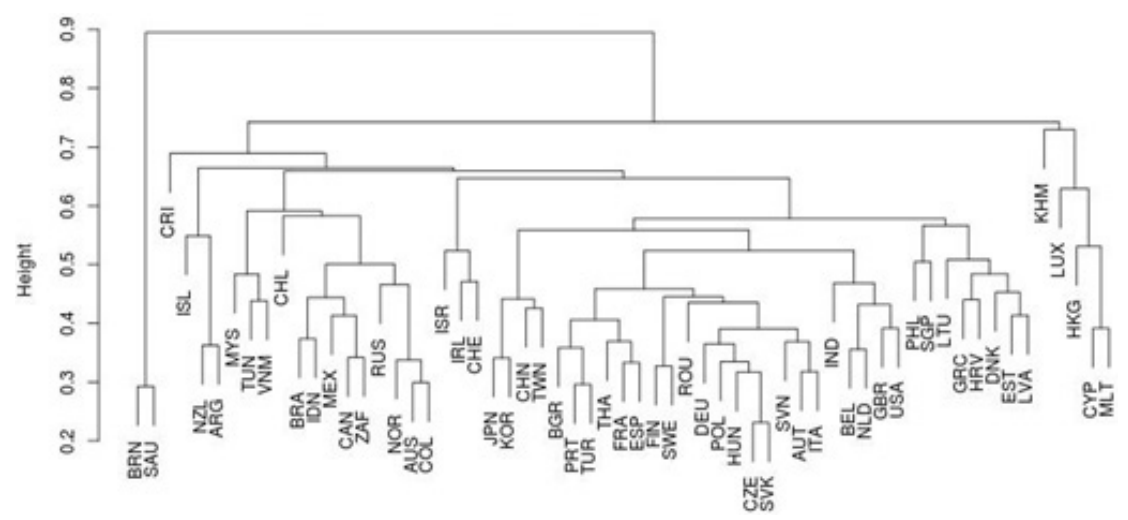

Figure 5. Cluster analysis - RCA in value added exports 2011

and interdependent global economy and where the role of exports has increased significantly during the transformation. Due to a strong dependence on foreign capital they are called dependent market economies. The findings confirm that V4 countries are largely linked to the GPN in comparison to other countries. The participation index increased between 1995 and 2011 and now stands at over $70 \%$ in Czechia, Slovakia and Hungary and almost $60 \%$ in Poland and is among the highest in the world. Domestic value added is in many aspects more important than gross exports, especially in terms of employment and economic growth. However, the foreign value added in V4 countries' exports (the backward participation) increases steadily and now reaches over 45\% (37\% in Poland). On the other hand, the domestic value added exports embodied in third countries' exports (the forward participation) is much lower (around 25\%). This is related among other things to the large dependence on foreign capital and their position as manufacturing export platforms.

Geographic proximity and economic integration are the major factors that affect the structure of Visegrad countries export destinations and thus V4 are strongly linked to each other in regional value chains. Most of the foreign value added originates from developed countries and most of the domestic value added by V4 countries (over 70\%) is destined for the developed countries. Over time the role of the EU and especially Germany in both imports and exports has increased within GPN, however, due to the decreasing role of Russia the global GPN in V4 countries are emerging faster than regional GPN. This is consistent with the findings of Los et al. (2015). Furthermore, less than half of V4 countries' exports to Germany are domestic value added exports destined for the German market. This makes V4 countries more vulnerable to changes in the global market.

All V4 countries are highly industrialized countries with a significant role being played by manufacturing and similar industrial orientations. The most important export industries are 'Transport equipment', 'Electrical and optical equipment', 'Chemicals and nonmetallic mineral products' and 'Basic metals and fabricated metal products', which together account for over $50 \%$ of all exports. Both 'Electrical and optical equipment' and 'Transport equipment' industries belong to the most organisationally fragmented ones and thus there is a high participation index and also a large share of FVA in exports. V4 countries (except Poland) have been shown to have a major comparative advantage in gross and VA exports in 'Motor vehicles, trailers and semi-trailers'. Based on the 'industry space' V4 countries and also Germany have very similar industrial orientations. On the other hand, in all V4 countries the share of services 
in VA exports is low and has increased only slightly over the period. Despite the rising numbers of graduates especially in social sciences, the services value added remains low. This is problematic since services are associated with higher gains in terms of VA. In addition to this, the major comparative advantage of V4 countries is still derived from the relatively cheap and skilled labour force. Increasing industrial robotization and automatization is thus a huge challenge for V4 countries.

The differences between Visegrad countries are rather small. Czechia remains the richest country with lowest unemployment rates and closest linkages with Germany. This is related to its better starting position in the early 1990s, although one of the major problems is stagnating productivity. Hungary is the most dependent on foreign capital, with high backward linkages, though this is likely affected by its more open attitude towards foreign capital since the 1980s. Hungarian firms are the most successful in terms of internationalization (at least based on FDI outflow). Slovakia has made major progress in productivity (and GDP) growth, although it has the highest dependence on exports. Poland is the biggest economy and this is reflected in its lower dependence on foreign capital and exports, lower GPN participation and backward linkages. Apart from that, the slightly more diversified industrial structure also plays a role.

Participation in GPN has definitely brought benefits to V4 countries, such as employment and economic growth, though in terms of spillovers the results are mixed. Less attention has been paid to negative effects such as the impacts on domestic companies, preference of low to medium-skilled jobs and especially profit repatriations. Domestic value added created in V4 countries is lower than exports indicate and as current account deficits and recent research (e.g. Pavlínek \& Ženka 2016) confirm, a large proportion of the value created in V4 countries is controled and captured by other economies. The main objective of V4 countries should be to improve their position in GPN and create, control and capture as much value added as possible. Favourable business and investment climates including labour laws, taxation and anti-corruption strategies are crucial and this should be reflected in investment, education and other policies. Unlike in Germany there is no industrial policy. In addition, more attention and support should be given to domestically-owned firms in terms of their development as well as internationalization. Nonetheless, organisation of GPN and strategies of TNCs are also very important, and in this respect V4 countries have relatively limited bargaining power (Blažek 2012). TiVA data help to assess the position of V4 countries, however in order to assess the costs and benefits associated with participation in GPN and account for the differences in organization and coordination of GPN and how it has evolved in Central Europe in line with the GPN 2.0, both qualitative and quantitative research need to be combined. In further studies more attention should be paid to the changing dynamics of GPN and the situations in particular industries which take into account the large variations between firms within industries. This requires using firm-level data and on-site surveys.

\section{Acknowledgements}

This article was created within the IGA project "Changes in the EU-US Transatlantic Partnership - Can the Platform continue to overcome security and economic challenges for Europe?" No. F2/63/2018, at the University of Economics, in Prague.

\section{Editors' note:}

Unless otherwise stated, the sources of tables and figures are the authors', on the basis of their own research. 


\section{References}

Aggarwal A., Berry O., Kenney M., Lenway S.A., TAYLOR V., 2008. Corporate strategies for software globalisation [in:] L. Labrianidis (ed.), The moving frontier: The changing geography of production in labour-intensive industries, Aldershot: Ashgate, pp. 255-280.

Amador J., \& Cabral S., 2014. Global value chains: A survey of drivers and measures. Journal of Economic Surveys, vol. 28, no. 3, pp. 401-593.

BALDWIN R., 2006. Globalisation: The great unbundling (s). Paper prepared for Finnish Prime Minister's Office for EU Presidency.

Baldwin R., Lopez-Gonzalez J., 2015. Supply chain trade: A portrait of global patterns and several testable hypotheses. The World Economy, vol. 38, no. 11, pp. 1682-1721.

BALASSA B., 1965. Trade liberalisation and 'revealed' comparative advantage. The Manchester School, vol. 33, no. 2, pp. 99-123.

Barrientos S., Gereffi G., Rossi A., 2011. Economic and social upgrading in global production networks: A new paradigm for a changing world. International Labour Review, vol. 150, no. 3-4, pp. 319-340.

BLAŽEK J., 2012. Regionální inovační systémy a globální produkčni sitě: dvojí optika na zdroje konkurenceschopnosti v současném světě. Geografie-Sborník ČGS, vol. 117, no. 2, pp. 209-233.

BLAŽEK J., 2015. Towards a typology of repositioning strategies of GVC/GPN suppliers: The case of functional upgrading and downgrading. Journal of Economic Geography, vol. 16, no. 4, pp. 849-869.

Capik P., Drahokoupil J., 2011. Foreign direct investments in business services: Transforming the Visegrád four region into a knowledgebased economy? European Planning Studies, vol. 19, no. 9, pp. 1611-1631.

Coe N.M., Dicken P., Hess M., 2008. Global production networks: Realizing the potential. Journal of Economic Geography, vol. 8, no. 3, pp. 271-295.

De BaCKer K., Miroudot S., 2013. Mapping global value chains. OECD Trade Policy Paper, no. 159.

DiCKEN P., 2015. Global shift: Mapping the changing contours of the world economy. London: Sage Publications.
Dischinger M., Knoll B., Riedel N., 2014. There's no place like home: The profitability gap between headquarters and their foreign subsidiaries. Journal of Economics \& Management Strategy, vol. 23, no. 2, pp. 369-395.

DomansKI B., Gwosdz K., 2009. Toward a more embedded production system? Automotive supply networks and localized capabilities in Poland. Growth and Change, vol. 40, no. 3, pp. 452-482.

DrahoKoupIL J. 2009. Globalization and the state in Central and Eastern Europe: The politics of foreign direct investment. London-New York: Routledge.

Egger H., Egger P., 2005. The determinants of EU processing trade. The World Economy, vol. 28, no. 2, pp. 147-168.

ERNST D., KIM L., 2002. Global production networks, knowledge diffusion, and local capability formation. Research policy, vol. 31, no. 8-9, pp. 1417-1429.

Feenstra R.C., Hanson G.H., Swenson D.L., 1998. Offshore assembly from the United States: Production characteristics of the 9802 program. Working Paper series, no. 31, Davis: University of California.

Ferrarini B., 2011. Mapping vertical trade. Manila: Asian Development Bank.

Ferrarini B., Hummels D., (eds.), 2014. Asia and global production networks: Implications for trade, incomes and economic vulnerability. Cheltenham: Edward Elgar Publishing.

FORTWENGEL J., 2011. Upgrading through integration? The case of the Central Eastern European automotive industry. Transcience Journal, vol. 2, no. 1, pp. 1-25.

Gereffl G., 1994. The organisation of buyer-driven global commodity chains: How US retailers shape overseas production networks [in:] G. Gereffi, M. Korzeniewicz (eds.), Commodity chains and Global Capitalism, Westport-London: Praeger, pp. 95-95.

Gereffi G., Fernandez-Stark K., 2011. Global value chain analysis: A primer. Center on Globalization, Governance \& Competitiveness (CGGC), Duke University, North Carolina, USA.

Gereffi G., Humphrey J., Sturgeon T., 2005. The governance of global value chains. Review of international political economy, vol. 12, no. 1, pp. 78-104. 
Henderson J., Dicken P., Hess M., Coe N.M., YEUNG H.W.C., 2002. Global production networks and the analysis of economic development. Review of International Political Economy, vol. 9, no. 3, pp. 436-464.

Hidalgo C.A., Klinger B., Barabási A.L., HausMANN R., 2007. The product space conditions the development of nations. Science, vol. 317, no. 5837, pp. 482-487.

Hummels D., Jørgensen R., MunCh J.R., Xiang C., 2011. The wage effects of offshoring: Evidence from Danish matched worker-firm data. Working paper series, no. W17496, Cambridge, MA: National Bureau of Economic Research.

Humphrey J., LeCler Y., Salerno M.S. (eds.), 2000. Global strategies and local realities: The auto industry in emerging markets. Houndmills: Macmillan Press.

Humphrey J., SChmitz H., 2002. How does insertion in global value chains affect upgrading in industrial clusters?. Regional studies, vol. 36, no. 9, pp. 1017-1027.

IHNED, 2017. Pro menší české firmy je digitalizace jen heslo. Chybí jim kapitál, stát nabídne pomoc. Hospodářské Noviny, https://byznys. ihned.cz/c1-65769410-pro-mensi-ceske-firmyje-digitalizace-jen-heslo-chybi-jim-kapital-statnabidne-pomoc [Accessed June 2017].

Jakab Z.M., Kovács M.A., Oszlay A., 2001. How far has trade integration advanced?: An analysis of the actual and potential trade of three Central and Eastern European countries. Journal of Comparative Economics, vol. 29, no. 2, pp. 276-292.

Jürgens U., KRZYWDZINSKI M., 2009. Changing East-West division of labour in the European automotive industry. European Urban and Regional Studies, vol. 16, no. 1, pp. 27-42.

Koopman R., Wang Z., Wel S.-J., 2008. How much Chinese exports is really made in China - Assessing foreign and domestic valueadded in gross exports. NBER Working Paper, no. 14109, Washington, DC: Office of Economics, United States International Trade Commission.

Koopman R., Powers W., Wang Z., Wei S.-J., 2010. Give credit to where credit is due: Tracing value added in global production chains. NBER Working Papers, no. 16426, Cambridge, Mass.: National Bureau of Economic Research.
Koopman R., Wang Z., Wel S.-J., 2012. Tracing value-added and double counting in gross exports. NBER Working Paper, no. w18579, Cambridge, Mass. National Bureau of Economic Research.

Los B., Timmer M.P., VRies G.J., 2015. How global are global value chains? A new approach to measure international fragmentation. Journal of Regional Science, vol. 55, no. 1, pp. 66-92.

MicEK G., 2015. Global value chains: The case of the software industry in Poland [in:] J. Vlčková (ed.), How to benefit from Global Value Chains - Implications for the V4 countries, Prague: Oeconomica, pp. 98-115.

MudambI R., 2008. Location, control and innovation in knowledge-intensive industries. Journal of Economic Geography, vol. 8, no. 5, pp. 699-725.

Myant M., DrahokouplL J., 2012. International integration, varieties of capitalism and resilience to crisis in transition economies. Europe-Asia Studies, vol. 64, no. 1, pp. 1-33.

Nölke A., Vliegenthart A., 2009. Enlarging the varieties of capitalism: The emergence of dependent market economies in East Central Europe. World Politics, vol. 61, no. 4, pp. 670-702.

Novotný J., Cheshire J.A., 2012. The surname space of the Czech Republic: Examining population structure by network analysis of spatial cooccurrence of surnames. PloS one, vol. 7, no. 10, e48568.

OECD-WTO, 2016. Trade in Value Added (TiVA): December 2016. Organisation for Economic Co-operation and Development, https://stats. oecd.org/index.aspx? queryid=75537 [Accessed March 2017]

OICA, 2016. Production statistics. International Organization of Motor Vehicle Manufacturers, http://www.oica.net/category/productionstatistics/2016-statistics/ (Accessed March 2017)

Pavlínek P., 2004. Regional development implications of foreign direct investment in Central Europe. European Urban and Regional Studies, vol. 11, no. 1, pp. 47-70.

PAVLíneK P., 2012. The internationalization of corporate $R \& D$ and the automotive industry $R \& D$ of East-Central Europe. Economic Geography, vol. 88 , no. 3, pp. 279-310. 
Pavlínek P., Domański B., Guzik R., 2009. Industrial upgrading through foreign direct investment in Central European automotive manufacturing. European Urban and Regional Studies, vol. 16, no. 1, pp. 43-63.

PAVLÍNEK P., ŽenKA J., 2010. Upgrading in the automotive industry: Firm-level evidence from Central Europe. Journal of Economic Geography, vol. 11, no. 3, pp. 559-586.

PaVlíneK P., ŽenKa J., 2016. Value creation and value capture in the automotive industry: Empirical evidence from Czechia. Environment and Planning A, vol. 48, no. 5, pp. 937-959.

Pavlínek P., Žížalová P., 2014. Linkages and spillovers in global production networks: Firmlevel analysis of the Czech automotive industry. Journal of Economic Geography, vol. 14, no. 1, pp. 1-33.

Peter K.S., Švejnar J., Terrell K., 2012. Foreign investment, corporate ownership, and development: Are firms in emerging markets catching up to the world standard? Review of Economics and Statistics, vol. 94, no. 4, pp. 981-999.

Plank L., Staritz C., 2013. 'Precarious upgrading' in electronics global production networks in Central and Eastern Europe: The cases of Hungary and Romania. Capturing the Gains Working Paper, no. 31, University of Manchester.

Porter M.E. 1985. Competitive advantage: Creating and sustaining superior advantage. London: MacMillan.

Roaf M.J., Atoyan R., Joshi B., Krogulski M.K., 2014. Regional Economic Issues: Special Report 25 Years of Transition: Post-Communist Europe and the IMF. International Monetary Fund.

Sass M., Szalavetz A., 2014. R\&D-based integration and upgrading in Hungary. Acta Oeconomica, vol. 64, suppl. 1, pp. 153-180.

Suøholt P., VAtne E., 2012. Understanding the role of services in the globalisation process: The case of Norway. Norsk Geografisk TidsskriftNorwegian Journal of Geography, vol. 66, no. 2, pp. 99-112.

Smith A., Pickles J., BuČek M., PÁstor R., Begg B., 2014. The political economy of global production networks: Regional industrial change and differential upgrading in the East European clothing industry. Journal of Economic Geography, vol. 14, no. 6, pp. 1023-1051.
Smith A., Rainnie A., Dunford M., Hardy J., Hudson R., SAdler D., 2002. Networks of value, commodities and regions: Reworking divisions of labour in macro-regional economies. Progress in Human Geography, vol. 26, no. 1, pp. 41-63.

STERN N., 1997. The transition in Eastern Europe and the former Soviet Union: Some strategic lessons from the experience of 25 countries over six years [in:] S. Zecchini (ed.), Lessons from the Economic Transition, Dordrecht: Springer Netherlands, pp. 35-57.

Sturgeon T.J., Memedovic O., Van Biesebroeck J., GerefFI G., 2008. Globalisation of the automotive industry: Main features and trends. International Journal of Technological Learning, Innovation and Development, vol. 2, no. 1-2, pp. 7-24.

TAČR, 2015. Projekt Mapování inovační kapacity - INKA. Available at: https://www.tacr.cz/ dokums_raw/prezentace/inka.pdf [October 2018].

Timmer M.P., Dietzenbacher E., Los B., StehrER R., DE VRIES G.J., 2015. An illustrated user guide to the world input-output database: The case of global automotive production. Review of International Economics, vol. 23, no. 3, pp. 575-605.

VLČKOVÁ J., 2015. Can exports be used as an indicator of technological capabilities of countries. Geografie, vol. 120, no. 3, pp. 314-329.

WANG J., LeE C., 2007. Global production networks and local institution building: The development of the information-technology industry in Suzhou, China. Environment and Planning A, vol. 39, no. 8, pp. 1873-1888.

WORLD BANK, 2016. Exports of goods and services (\% of GDP). http://data.worldbank.org/indicator/NE.EXP.GNFS.ZS [Accessed May 2017].

WTO, 2010. Measuring international trade in value added for a clearer view of globalization. Conference proceedings, World Trade Organization, Paris, 15 October 2010.

YEATS A.J., 1998. Just how big is global production sharing?. Policy research working papers, no. 1871, Washington, DC: World Bank, Development Research Group. 
YeUnG H.W.C., 2009. Regional development and the competitive dynamics of global production networks: An East Asian perspective. Regional Studies, vol. 43, no. 3, 325-351.

YeUng H.W.C., Coe N., 2015. Toward a dynamic theory of global production networks. Economic Geography, vol. 91, no. 1, pp. 29-58. 